\title{
Cardiac, respiratory and thermoregulation parameters following graded exercises in Lipizzaner horses
}

\author{
Nina Čebulj-Kadunc¹, Robert Frangež ${ }^{1}$, Jaka Žgajnar², and Peter Kruljc ${ }^{1 *}$ \\ ${ }^{I}$ Veterinary Faculty, University of Ljubljana, Ljubljana, Slovenia \\ ${ }^{2}$ Department of Animal Science, Biotechnical Faculty, University of Ljubljana, Ljubljana, Slovenia
}

\begin{abstract}
ČEBULJ-KADUNC, N., R. FRANGEŽ, J. ŽGAJNAR, P. KRULJC: Cardiac, respiratory and thermoregulation parameters following graded exercises in Lipizzaner horses. Vet. arhiv 89, 11-23, 2019.
\end{abstract}

\section{ABSTRACT}

The sport results or exercise achievements of Lipizzaner horses are rarely considered, as their involvement in equestrian sports is rare. As a result, norms for evaluation of their fitness level during training or performance have not yet been determined. The aim of this study was to determine the basal values of various physiological parameters (heart rate (HR), respiration rate (RR), body and skin temperatures) and their acclimatisation to a graded exercise load. The study was performed with a group of 6 purebred Lipizzaner horses with an average age of 9 years. It consisted of two trials (spring, autumn) of exercise test, including lunging at a walk, trot and canter. The physiological values were measured before and after exercise, and were within the normal ranges for warm-blooded horses in both trials. A gradual increase in HR and significant positive correlations between HR and speed were determined in the Lipizzaners during the exercise tests in both trials, which was followed by a gradual increase in RR, rectal temperature and the skin temperature in various body regions. The time to reach resting HR after exercise was longer in spring than in autumn. Resting RRs and rectal temperatures were reached at the time to reach resting HR. Differences between the resting skin temperatures of various body regions were determined in both trials. Following the exercise test, the skin temperatures of all regions were significantly higher when compared to the resting values, and decreased thereafter during the recovery time in autumn, but remained almost unchanged in spring. The study contributes to knowledge about thermoregulation and the response of the cardiovascular and respiratory parameters of horses. The results are not only a presentation of physiological responses to graded exercise in Lipizzaner horses, but may be accepted as an important contribution to sports physiology and medical knowledge about horses in general, representing a basis for further research in the field of exercise tests and sports medicine.

Key words: horse; heart rate; thermoregulation; exercise test

\footnotetext{
*Corresponding author:

Assist. Prof. Peter Kruljc, DVM, PhD, University of Ljubljana, Veterinary Faculty, Gerbiceva 60, SI-1000 Ljubljana, Slovenia, Phone: +386 14779 100; Fax: +386 128322 43; E-mail: peter.kruljc@vf.uni-lj.si
} 
N. Čebulj-Kadunc et al.: Physiological responses of Lipizzaner horses to graded exercise

\section{Introduction}

Sport horses are often subjected to various forms of physical and emotional stress, leading to different diseases and injuries, which weaken their physical fitness and work performance (SLOET VAN OLDRUITENBORGH-OOSTERBAAN et al., 1991; MUNSTERS et al., 2014). The fitness level of horses can be evaluated by exercise tests. On the basis of cardiovascular and metabolic responses, as well as musculoskeletal acclimatisation to exercise, standard procedures for exercise tests have been designed in the form of treadmill or field exercise tests (SLOET VAN OLDRUITENBORGHOOSTERBAAN et al., 1991; MUNSTERS et al., 2014). Various external factors, such as ambient temperature and humidity (MARLIN et al., 1996; HARGREAVES et al., 1999), rider and tack (HARGREAVES et al., 1999) or track surface (SLOET VAN OLDRUITENBORGH-OOSTERBAAN et al., 1991; HARGREAVES et al., 1999) influence the results of field exercise tests. However, field tests have advantages over the use of a treadmill in more technically sophisticated equestrian disciplines, such as dressage or show jumping (SLOET VAN OLDRUITENBORGH-OOSTERBAAN et al., 1999). A wide variety of exercise tests have been described, including incremental exercise tests, indoor riding tests and lunging tests, considering the demands of different equestrian disciplines (SLOET VAN OLDRUITENBORGH-OOSTERBAAN et al., 1991; HARRIS et al., 2007; MUNSTERS et al., 2013; MUNSTERS et al., 2014). An important index of fitness determined in exercise tests is heart rate (HR), which can be measured by portable HR monitors (AERTS et al., 2008; SLOET VAN OLDRUITENBORGH-OOSTERBAAN et al., 2008; MUNSTERS et al., 2013; MUNSTERS et al., 2014). The performance of horses during exercise tests can be affected by disturbances of thermoregulation, especially under hot and humid conditions (HARGREAVES et al., 1999; McKEEVER et al., 2010) or in horses not acclimated to the environmental temperatures (MARLIN et al., 1996, McKEEVER et al., 2010). Therefore, skin temperature (ST) may be an useful indicator of changes in acute thermoregulatory acclimatisation (JODKOWSKA et al., 2011) and can be successfully measured by infrared thermography (JODKOWSKA et al., 2011; SIMON et al., 2006; REDAELLI et al., 2014).

The Lipizzaner is one of the oldest European horse breeds. Due to the small number of horses and the relative dispersion of breeders, the breed is considered endangered (ANONYM., 2016). Lipizzaner stallions achieve superior results in classical dressage, but the breed has also gained popularity in modern equestrian sports such as dressage and combined driving (DRUML, 2011). The physiological reactions of Lipizzaner horses (Lipizzaners) to workload are poorly known, and norms for evaluation of their fitness level during training or performance have not yet been determined. Therefore, the aim of our study was to determine the basal values of some physiological parameters (HR, respiration rate, body and STs) and their acclimatisation to a graded exercise load. 
The results of our study will serve as a basis for formation of norms and protocols for monitoring fitness levels and training progress in Lipizzaners, and will offer support for health status monitoring and assessment of the well-being of horses.

\section{Materials and methods}

Animals. The study was performed at the Pedagogical and Research Equestrian Centre at Krumperk (Department of Animal Sciences, Biotechnical Faculty, University of Ljubljana, Slovenia), with 6 pure-bred Lipizzaners (3 geldings, 2 mares, 1 stallion) with an average age of $9 \pm 0.8$ years and an average body mass of $455 \pm 36 \mathrm{~kg}$. The horses were mainly used in student equitation courses five days per week, with their daily workload rarely exceeding 4 hours, or they were exercised using a walking machine. On days without precipitation, they spent an additional 6 hours daily at pasture.

The use of the animals and their care were implemented according to the protocol approved by the Commission for Animal Welfare of the Veterinary Faculty, University of Ljubljana.

The horses were housed in a stable, within individual boxes bedded with sawdust. They were fed twice a day, with an average daily amount of $10 \mathrm{~kg}$ of hay and 7 litres of squeezed oats, with $100 \mathrm{~g}$ of Kovisal (Jata Emona d.o.o., Ljubljana, Slovenia) vitaminmineral mixture added, and they had free access to automatic waterers. The horses were dewormed with the anthelminthic paste Noromectin Praziquantel Duo (Norbrook ${ }^{\circledR}$ Laboratories Limited, Newry, United Kingdom) twice per year, according to the manufacturer's instructions.

With regards to clinical examinations and individual histories, the studied horses were deemed clinically healthy throughout the study. The mares included in the study were not pregnant.

Test protocol and physical activity. The study consisted of two exercise tests, performed by lunging. The first test was implemented in May in an open-air riding arena $(20 \times 60 \mathrm{~m}$ with sand footing) and the second one in October of the same year in an indoor riding arena $(13 \times 29 \mathrm{~m}$ with sand footing), enabling a lunging radius of $8.5 \mathrm{~m}$ and $6 \mathrm{~m}$ in the first and second tests, respectively. All six horses were tested in both trials, with lunging performed by the same experienced handler, who was familiar with the individual horses.

The exercise test protocol (Table 1) consisted of 8 phases, with specific activities (lunging at a walk, trot and canter, or resting) and measurements of physiological values (STs of various body regions, rectal temperatures, respiratory and HRs) and environmental parameters (air temperature and humidity). Each test was preceded by a 5-minute walk from the stable to the riding arena (Phase 1; Ph-1) and a 10 minute rest that was devoted to measurement of the basal values of the physiological parameters (Phase $2 ; \mathrm{Ph}-2$ ). 
Each horse was then lunged for 30 minutes at a walk, trot and canter (for 10 minutes at each gait), and left and right reins were exchanged every 5 minutes (Phase 3 to Phase 5; Ph-3 to Ph-5). This was followed by a 10-minute break (Phase 6; Ph-6) intended for repetition of the measurements, and then by 10 minutes of lunging at a walk (Phase 7; Ph7). Thereafter, each horse was returned to its stall (Phase 8; Ph-8), and the measurements were repeated again when the basal HR was recovered.

Table 1. Protocol for exercise test

\begin{tabular}{|l|c|c|c|c|}
\hline $\begin{array}{l}\text { Phase of } \\
\text { the test }\end{array}$ & $\begin{array}{c}\text { Duration of } \\
\text { activity (min) }\end{array}$ & Location & Activity & Recorded parameters \\
\hline Ph-1 & 5 & Stable & $\begin{array}{c}\text { Rest; } \\
\text { Placing of monitor }\end{array}$ & HR, AT, AH \\
\hline $\mathrm{Ph}-2$ & 10 & Riding arena & Rest & HR, RR, ST, RT, AT, AH, \\
\hline $\mathrm{Ph}-3$ & 10 & Riding arena & Lunging (walk) & LN \\
\hline $\mathrm{Ph}-4$ & 10 & Riding arena & Lunging (trot) & LN \\
\hline $\mathrm{Ph}-5$ & 10 & Riding arena & Lunging (canter) & LN \\
\hline $\mathrm{Ph}-6$ & 10 & Riding arena & Rest & HR, RR, ST, RT, AT, AH, \\
\hline $\mathrm{Ph}-7$ & 10 & Riding arena & Lunging (walk) & LN \\
\hline $\mathrm{Ph}-8$ & $\begin{array}{c}\text { Until resting } \\
\text { HR reached }\end{array}$ & Stable & Rest & HR, RR, ST, RT, AT, AH, \\
\hline
\end{tabular}

Ph-1 to Ph- 8 - Phases 1 to 8 of the test; AT - air temperature, AH - air humidity; ST - skin temperature of various regions); RT - rectal temperature, RR - respiratory rate, HR - heart rate; LN - number of laps)

Measurements and equipment. Heart rate (HR) was measured telemetrically with a transmitter (Polar Equine H3 heart rate sensor belt set (Polar Electro, Kempele, Finland), and a receiver (Polar Equine V 800, Polar Electro, Kempele, Finland). The electrodes and transmitter were positioned on the left side of the thorax behind the withers and elbow, with an elastic belt. To improve the contact between the skin and the registration electrodes, the belt and skin were lubricated with ECG liquid gel Ultra Vete (Transpharma, Muggia, Italy).

The receiver was fixed to the head collar (left side of the crownpiece). The equipment for HR monitoring was installed in the stable before the onset of the trial and removed after its completion. The data were transferred to a computer after the end of the experiment. The Polar Flow application (Polar Electro, Kempele, Finland) was used for display and registration of the HRs.

Respiratory rate was measured directly by counting the movements of the ribcage and belly for 60 seconds. The rectal temperature was measured by a digital thermometer, Geratherm Flex (Geratherm Medical AG, Geschwenda, Germany). Body weight was evaluated by a Horse \& Pony Weighing Tape (Equi-Vet, Kruuse, Langeskov, Denmark). Distances covered while walking, trotting and cantering during each individual exercise 
test were calculated using the lunging radius and the number of laps covered during each gait (Ph-3 to $\mathrm{Ph}-5)$. Average speeds were calculated by dividing the distance travelled by the time.

STs were measured by an infrared thermal imaging camera FLIR (model E40bx, FLIR systems, Wilsonville, OR, USA) at a distance between $0.75-1.0 \mathrm{~m}$ from the left and right side of each body region (neck (R. coli lateralis), breast (R. pectoralis), back (R. lumbalis), croup (R. sacralis) and buttock (R. femoralis)) before lunging (Ph-3), immediately after lunging (Ph-6), and during recovery (Ph-8). Environmental temperature and humidity were measured by a digital humidity measuring instrument, Testo 635 (Testo AG, Lenzkirch, Germany), and the results are presented in Table 2.

Table 2. Air temperatures and air humidity (mean \pm SD) before exercise $(\mathrm{Ph}-2)$, immediately after exercise (Ph-5) and during recovery $(\mathrm{Ph}-8)$ in the May and October tests

\begin{tabular}{|l|c|c|c|c|}
\hline \multirow{2}{*}{ Parameter } & \multirow{3}{|c|}{ Phase } \\
\cline { 3 - 5 } & Trial & Ph-2 & Ph-5 & Ph-8 \\
\hline \multirow{2}{*}{ Air temperature $\left({ }^{\circ} C\right)$} & May & $18.42 \pm 0.77^{\mathrm{a}}$ & $21.10 \pm 0.77^{\mathrm{a}}$ & $21.27 \pm 0.68^{\mathrm{a}}$ \\
\cline { 2 - 5 } & October & $11.38 \pm 0.70^{\mathrm{a}}$ & $11.95 \pm 0.73^{\mathrm{a}}$ & $12.48 \pm 0.71^{\mathrm{a}}$ \\
\hline \multirow{2}{*}{ Air humidity $(\%)$} & May & $62.48 \pm 4.32^{\mathrm{b}}$ & $55.33 \pm 3.94^{\mathrm{c}}$ & $50.63 \pm 4.20^{\mathrm{b}}$ \\
\cline { 2 - 5 } & October & $81.47 \pm 4.62^{\mathrm{b}}$ & $85.80 \pm 4.78^{\mathrm{c}}$ & $84.15 \pm 5.09^{\mathrm{b}}$ \\
\hline
\end{tabular}

${ }^{a, b} \mathrm{P}<0.001 ;{ }^{\mathrm{C}}<0.01$ for values in the same column

Data analysis. Data were analysed using SPSS 20.0 IBM commercial software (Chicago, USA). One-way repeated measures ANOVAs (RM ANOVA) were used for comparison of results between phases for each trial, and between trials for each phase. Normality was assessed with the Shapiro-Wilk test, and significance was determined with all pairwise multiple comparison procedures (Tukey test). The Pearson product moment correlation was used to examine correlations between the results. To compare STs between the selected regions on the left and right sides of the horses, a paired Student t-test was applied. One-way ANOVA followed by Holm-Sidak testing for multiple comparisons was performed to compare ST $\times$ phase $\times$ trial interactions. The values are expressed as the means \pm standard deviation. The differences are considered significant at $\mathrm{P} \leq 0.05$.

\section{Results}

Average distances cowered during the exercise tests in May in October were respectively $794 \pm 25 \mathrm{~m}$ and $785 \pm 78 \mathrm{~m}$ for walking, $1851 \pm 38 \mathrm{~m}$ and $1828 \pm 48 \mathrm{~m}$ for trotting and $3089 \pm 10 \mathrm{~m}$ and $2432 \pm 81 \mathrm{~m}(\mathrm{P}<0.05)$ for cantering. Average speeds reached during both tests were respectively $4.6 \pm 0.1 \mathrm{~km} / \mathrm{h}$ and $4.7 \pm 0.5 \mathrm{~km} / \mathrm{h}$ for walking, 10.8 $\pm 0.2 \mathrm{~km} / \mathrm{h}$ and $11.0 \pm 0.3 \mathrm{~km} / \mathrm{h}$ for trotting and $17.7 \pm 0.8 \mathrm{~km} / \mathrm{h}$ and $14.6 \pm 0.5 \mathrm{~km} / \mathrm{h}$ $(\mathrm{P}<0.05)$ for cantering. 
The changes in HR followed similar patterns in both exercise tests with peak values (132 \pm 6 and $126 \pm 12$ beats per minute, respectively) reached in Ph-6 (Fig. 1). The differences between various phases of each trial (Figure 1) were significant $(\mathrm{P}<0.00001$ for May and October). HR in Ph-7 was significantly higher in May than in October $(\mathrm{P}=$ 0.005). The differences between May and October HRs were insignificant in other phases $(\mathrm{P}>0.05)$.

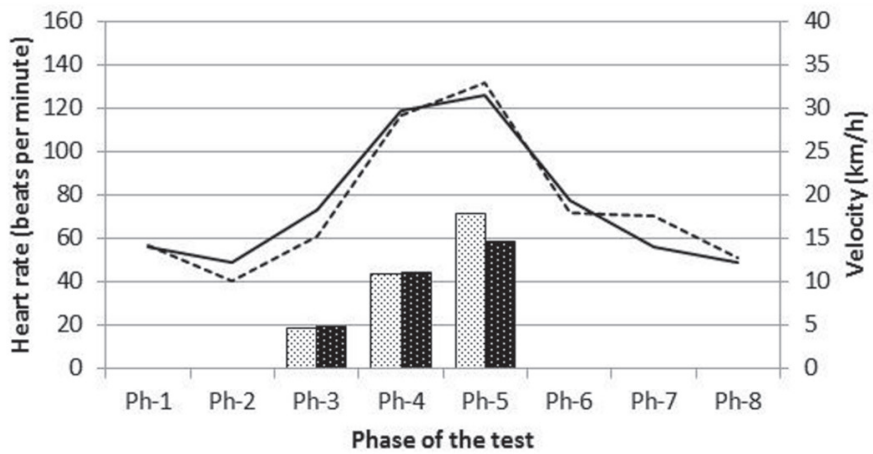

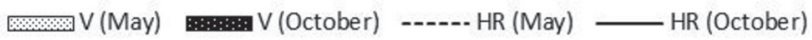

Fig. 1. Average heart rate and gait velocity in the May and October tests; V (May): velocity in May;

V (October): velocity in October; HR (May): heart rate in May; V (October): heart rate in October

The time to reach resting HR was $22.8 \pm 2.8 \mathrm{~min}$ in May and $19.3 \pm 2.2 \mathrm{~min}$ in October $(\mathrm{P}=0.291)$. The correlation coefficients $(\mathrm{R})$ between the HR and speed were 0.832 for May $(\mathrm{P}<0.001)$ and 0.629 for October $(\mathrm{P}<0.005)$.

Respiratory rates (RRs) and rectal temperatures before exercise, immediately after exercise and during recovery are presented in Table 3 . The changes in RRs as well as rectal temperatures followed similar patterns in May and October, with an increase in both values immediately after exercise. Differences between phases of the May and October tests were insignificant for both parameters $(\mathrm{P}>0.05)$.

The skin temperatures (STs) of various body regions before both exercise tests $(\mathrm{Ph}-2)$, immediately after exercise test $(\mathrm{Ph}-6)$ and during recovery $(\mathrm{Ph}-8)$ are presented in Table 4. The differences between the left and right sides of all body regions were insignificant in both months. Therefore, temperatures obtained on both sides of each region were used for further calculations. The ANOVA displayed significant differences $(\mathrm{P}<0.0001)$ in mean STs between various body regions in all phases of the tests. In October, the mean basal STs of all body regions were lower than in May $(\mathrm{P}=0.05)$. 
N. Čebulj-Kadunc et al.: Physiological responses of Lipizzaner horses to graded exercise

Table 3. Respiratory rates and rectal temperatures before exercise (Ph-2), immediately after exercise (Ph-5) and during recovery (Ph-8) in the May and October tests

\begin{tabular}{|l|c|c|c|c|}
\hline \multirow{2}{*}{ Parameter } & \multirow{3}{|c|}{ Phase } \\
\cline { 2 - 5 } & Trial & Ph-2 & Ph-5 & Ph-8 \\
\hline \multirow{2}{*}{ Respiratory rate $(\mathrm{n} / \mathrm{min})$} & May & $19 \pm 3^{\mathrm{a}}$ & $54 \pm 8^{\mathrm{a}, \mathrm{b}}$ & $18 \pm 3^{\mathrm{b}}$ \\
\cline { 2 - 5 } & October & $12 \pm 2^{\mathrm{c}}$ & $30 \pm 5^{\mathrm{c}, \mathrm{d}}$ & $15 \pm 3^{\mathrm{d}}$ \\
\hline \multirow{2}{*}{ Rectal temperature $\left({ }^{\circ} \mathrm{C}\right)$} & May & $37.6 \pm 0.1^{\mathrm{cd}}$ & $38.6 \pm 0.2^{\mathrm{c}}$ & $38.1 \pm 0.1^{\mathrm{d}}$ \\
\cline { 2 - 5 } & October & $37.5 \pm 0.1^{\mathrm{a}, \mathrm{b}}$ & $38.3 \pm 0.2^{\mathrm{a}}$ & $38.05 \pm 0.1^{\mathrm{b}}$ \\
\hline
\end{tabular}

${ }^{a, b} \mathrm{P}<0.001 ;$, d $\mathrm{P}<0.01$ for values in the same row

The STs in $\mathrm{Ph}-2$ ranged from $26.5^{\circ} \mathrm{C}$ at the croup to $30.4{ }^{\circ} \mathrm{C}$ on the breast during the May test $(\mathrm{P}<0.0001)$, and from $22.8^{\circ} \mathrm{C}$ at the croup to $28.8{ }^{\circ} \mathrm{C}$ on the back during the October test $(\mathrm{P}=0.0004)$. A significant elevation of STs was determined immediately after the exercise test $(\mathrm{Ph}-6)$ when compared to the basal values $(\mathrm{Ph}-2)$ in May $(\mathrm{P}<0.001$ for buttocks, chest and neck, $\mathrm{P}=0.003$ for croup and $\mathrm{P}=0.005$ for the back) and in October ( $\mathrm{P}<0.0001$ for all regions $)$. In May, an insignificant elevation $(\mathrm{P}>0.05)$ of STs was observed at the end of the trial (Ph-8) when compared to the $\mathrm{Ph}-2$ for the buttock, croup, back and neck, while the chest temperature decreased slightly $(\mathrm{P}>0.05)$. In October, a significant decrease in the STs was observed when comparing $\mathrm{Ph}-6$ and $\mathrm{Ph}-8(\mathrm{P}=0.05$ for the buttocks, $\mathrm{P}=0.016$ for the neck, $\mathrm{P}=0.001$ for the loin, $\mathrm{P}=0.003$ for the chest), but the difference for the back was insignificant $(\mathrm{P}=0.095)$.

Table 4. Changes in the skin temperatures of various body regions before the exercise test (Phase 2; Ph-2), immediately after the exercise test (Phase 6; Ph-6) and during recovery (Phase 8; Ph-8) in both periods (May and October)

\begin{tabular}{|c|c|c|c|c|}
\hline \multirow[b]{2}{*}{ Body regions } & \multirow[b]{2}{*}{ Month } & \multicolumn{3}{|c|}{ Average skin temperature $\left({ }^{\circ} \mathrm{C}\right)$} \\
\hline & & $\mathrm{Ph}-2$ & $\mathrm{Ph}-6$ & $\mathrm{Ph}-8$ \\
\hline \multirow{2}{*}{ Buttocks } & May & $30.2 \pm 0.6^{\mathrm{A}, \mathrm{B}}$ & $33.4 \pm 1.6^{\mathrm{A}, \mathrm{B}}$ & $33.6 \pm 1.1^{\mathrm{A}, \mathrm{B}}$ \\
\hline & October & $26.8 \pm 1.8^{\mathrm{a}}$ & $32.6 \pm 0.7^{\mathrm{a}}$ & $30.7 \pm 0.7^{\mathrm{a}, \mathrm{b}}$ \\
\hline \multirow{2}{*}{ Croup } & May & $26.5 \pm 1.5$ & $29.6 \pm 2.1$ & $30.5 \pm 1.8$ \\
\hline & October & $22.7 \pm 2.2$ & $27.5 \pm 2.2$ & $26.1 \pm 2.3^{c}$ \\
\hline \multirow{2}{*}{ Back } & May & $27.7 \pm 1.3$ & $30.6 \pm 2.3$ & $31.38 \pm 1.3$ \\
\hline & October & $24.1 \pm 1.5$ & $29.1 \pm 1.3$ & $27.5 \pm 1.4^{\mathrm{c}}$ \\
\hline \multirow{2}{*}{ Chest } & May & $30.4 \pm 1.8^{\mathrm{A}}$ & $34.0 \pm 2.7^{\mathrm{A}, \mathrm{B}}$ & $33.6 \pm 1.4^{\mathrm{A}, \mathrm{B}}$ \\
\hline & October & $28.7 \pm 1.1^{\mathrm{b}}$ & $34.9 \pm 1.3$ & $32.0 \pm 1.5^{\mathrm{a}}$ \\
\hline \multirow{2}{*}{ Neck } & May & $29.8 \pm 1.6^{\mathrm{A}}$ & $33.1 \pm 2.0, \mathrm{~A}, \mathrm{~B}$ & $33.1 \pm 1.3^{\mathrm{B}}$ \\
\hline & October & $28.0 \pm 1.7^{\mathrm{a}, \mathrm{b}}$ & $32.5 \pm 2.0^{\mathrm{a}}$ & $30.2 \pm 1.5^{\mathrm{b}}$ \\
\hline
\end{tabular}

A,B,C $\mathrm{P}>0.05$ for values in a row with the same labels; other combinations of values for May in the same column are significantly different $(\mathrm{P}<0.05 ;$; $, \mathrm{b}, \mathrm{c} P>0.05$ for values in a column with the same labels; other combinations of values for October in the same column are significantly different $(\mathrm{P}<0.05)$ 
N. Čebulj-Kadunc et al.: Physiological responses of Lipizzaner horses to graded exercise

\section{Discussion}

This study presents the reactions of heart and respiratory rates and STs of Lipizzaners to graded exercise tests, performed in May and October with lunging at a walk, trot and canter. To the best of our knowledge, this is the first exercise testing study performed in this breed of horse.

The response of HR to exercise is a function of exercise intensity and reflects metabolic capacity. It can be influenced by several exogenous factors, such as the characteristics of the track, environmental conditions, and the training state and health status of the horse (SLOET VAN OLDRUITENBORGH-OOSTERBAAN et al., 1991; HARGREAVES et al., 1999; KOBAYASHI et al., 1999; MUNSTERS et al., 2014; ALLEN et al. 2016).

The HRs of the investigated Lipizzaners measured in their boxes slightly exceeded the basal ranges reported for other breeds (SLOET VAN OLDRUITENBORGHOOSTERBAAN et al., 1991; SERRANO et al., 2002; HARRIS et al., 2007; WALLSTEN et al., 2012; PADALINO et al., 2014), most likely due to slight excitement caused by the installation of the HR measuring equipment and departure from the stable. When the horses were standing still in the riding arena, their HRs returned to the basal values.

HRs increased gradually with the transitions from walk to trot, and thereafter to canter, and displayed a linear regression with gait velocity up to the maximal HR, which may exceed 200 beats/min in various horse breeds (HARGREAVES et al., 1999; SERRANO et al., 2002; VINCENT et al., 2006; HARRIS et al., 2007; MUKAI et al., 2007; PADALINO et al., 2014; ALLEN et al., 2016). Similar responses of HRs, correlating positively with speed progression, were also determined in the Lipizzaners in both months. In Lipizzaners, HRs during the walk and the trot, but not during the canter, were slightly higher in October than in May. This could be attributed to the smaller radius of the lunging circle and the slower canter in the indoor arena than in the outdoor arena, as also reported in the literature (HARRIS et al., 2007). The gait of the Lipizzaners examined was slower than reported for horses during riding (MUKAI et al., 2007; AERTS et al., 2008). In addition to the breed characteristics, slower speeds could be attributed to moving in circles, which may have forced the horses to adopt a less efficient combination of stride frequency and stride length compared with exercise in a straight line (HARRIS et al., 2007). The HR recovery after exercise ranged from 14 to $32 \mathrm{~min}$ in the examined horses, and was significantly longer in May than in October, most likely due to the higher ambient temperature in May (MARLIN et al., 1996).

The basal rectal temperatures of the Lipizzaners were within the range reported for warm-blooded horses (JODKOWSKA et al., 2011; PADALINO et al., 2014), increased insignificantly during physical activity as a result of accelerated heat production (REDAELLI et al., 2014) and remained elevated until each test was completed and resting heart rate had been reached (HARGREAVES et al., 1999). 
The resting respiratory rates of the Lipizzaners were within the ranges reported for warm-blooded horses (WALLSTEN et al., 2012; PADALINO et al., 2014), increased significantly during exercise and returned to basal levels during recovery. This pattern of RR reflects the physiological reaction of elevated oxygen consumption during exercise (HARGREAVES et al., 1999; WALLSTEN et al., 2012), but it also contributes to heat loss through evaporation (JODKOWSKA et al., 2011).

Metabolic activity in resting muscles produces a steady amount of heat that increases during exercise in proportion to the work load. To maintain a body temperature within the physiological range, various thermoregulatory mechanisms are activated that lead to elevation of the ST (JODKOWSKA et al., 2011; REDAELLI et al., 2014). As regards STs, horses are bilaterally symmetrical (JODKOWSKA et al., 2011; SIMON et al., 2006), as was also confirmed in this study in Lipizzaners, indicating balanced muscle work and an appropriate track surface. Resting STs in the investigated horses ranged from $26.5^{\circ} \mathrm{C}$ to $30.4{ }^{\circ} \mathrm{C}$ in May and from $22.7^{\circ} \mathrm{C}$ to $28.7^{\circ} \mathrm{C}$ in October, similar to those reported by other studies (SIMON et al., 2006; JODKOWSKA et al., 2011; WALLSTEN et al., 2012). The resting STs of the same regions were significantly lower in October than in May, and the differences between the STs of various regions were significant for both months, indicating different blood supplies to various parts of the skin and different shares of these regions in the thermoregulation functions of the horse (JODKOWSKA et al., 2011).

Following graded exercise, the STs of all regions increased significantly when compared to the basal values (Table 4), where this increase was more apparent in October than in May. The absolute STs, as well as the differences between STs before and after exercise, were similar to those measured in horses after show jumping competitions (JODKOWSKA et al., 2011) or treadmill tests (SIMON et al., 2006).

The STs of all body regions of the Lipizzaners, with the exception of the chest, increased slightly during the recovery time in May, but decreased in October. As already mentioned, we attribute this to the higher ambient temperature in May than in October, which reduced the efficiency of convection (REDAELLI et al., 2014). These findings also indicate that the high relative humidity measured in October (Table 2), which exceeded the critical value for sweat evaporation of $80 \%-85 \%$, did not hinder the cooling of the skin reported at high air temperatures (REDAELLI et al., 2014).

In conclusion, the resting HRs, RRs and rectal temperatures of the investigated Lipizzaners were within the ranges reported for warm-blooded horses. A gradual increase in HR and a significant positive correlations between the HR and speed were determined in Lipizzaners during the exercise tests in both months, which was also followed by a gradual increase in the RRs, rectal temperatures and STs of various body regions. HR recovery after exercise was longer in May than in October, most likely due to the higher ambient temperatures in May. Resting RRs and rectal temperatures were reached at the 
N. Čebulj-Kadunc et al.: Physiological responses of Lipizzaner horses to graded exercise

time of reaching resting HR. Differences between the resting STs of various body regions were determined in both trials. Following exercise tests, the STs of all regions were higher when compared to the resting values, and decreased thereafter during the recovery time in October, or remained almost unchanged in May. The results of our study present the physiological response of Lipizzaners to graded exercise and may be accepted as an important contribution to sports physiology and medicine pertaining to the Lipizzaner breed. This study also contributes to knowledge about thermoregulation and the responses of some cardiovascular and respiratory parameters of horses in various seasons, and to recognition of the complex physiological processes that take place during exercise, and represents a basis for further research in the field of exercise testing and sports medicine for horses.

\section{Acknowledgements}

The authors thank Mr. Matej Lončar, the staff and students of the Pedagogical and Research Centre for Horse Breeding Krumperk (Biotechnical Faculty, Department of Animal Science) for assistance in working with horses. The statistical analyses were performed by Hristo Hristov, PhD.

The study was financially supported by the Slovenian Research Agency (Grant number P4-0053).

\section{References}

ANONYMOUS (2016): Breeding Program for the Lipizzan Breed. (Online). http://www.lipica. org/si/stable/kobilarna/rejski-program. Accessed April 20, 2016.

AERTS, J. M., F. GEBRUERS, E. VAN CAMP, D. BERCKMANS (2008): Controlling horse heart rate as a basis for training improvement. Comput. Electron. Agric. 64, 78-84.

DOI: 10.1016/j.compag.2008.05.001.

ALLEN, K. J., L. E. YOUNG, S. H. FRANKLIN (2016): Evaluation of heart rate and rhythm during exercise. Equine Vet. Educ. 28, 99-112.

DOI: 10.1111 /eve.12405.

DRUML, T. (2011): Historical origin of the breed. In: The Lipizzan in the Mirror of Science. (Brehm, G., Ed.). Published by the Austrian Academy of Sciences. Vienna, pp. 9-32. (in German).

HARGREAVES, B. J., D. S. KRONFELD, J. R. J. NAYLOR (1999): Ambient temperature and relative humidity influenced packed cell volume, total plasma protein and other variables in horses during an incremental submaximal field exercise test. Equine Vet. J. 4, 314-318.

DOI: 10.1111/j.2042-3306.1999.tb03823x.

HARRIS, P., D. J. MARLIN, H. DAVIDSON, J. RODGERSON, A. GREGORY, D. HARRISON (2007): Practical assessment of heart rate response to exercise under field conditions. Equine Comp. Exerc. Physiol. 1, 15-21.

DOI: $10.1017 / \mathrm{S} 1478061507736459$. 
N. Čebulj-Kadunc et al.: Physiological responses of Lipizzaner horses to graded exercise

JODKOWSKA, E., K. DUDEK, M. PRZEWOZNY (2011): The maximum temperatures (Tmax) distribution on the body surface of sport horses. J. Life Sci. 5, 291-297.

KOBAYASHI, M., K. KURIBARA, A. AMADA (1999): Application of V200 values for evaluation of training effects in the young Thoroughbred under field conditions. Equine Vet. J. 30, 159162.

MARLIN, D. J., C. M. SCOTT, R. C. SCHROTER, P. C. MILLS, R. C. HARRIS, P. A. HARRIS, C. E. ORME, C. A. ROBERTS, C. M. MARR, S. J. DYSON, F. BARRELET (1996): Physiological responses in nonheat acclimated horses performing treadmill exercise in cool $\left(20^{\circ} \mathrm{C} / 40 \% \mathrm{RH}\right)$, hot dry $\left(30{ }^{\circ} \mathrm{C} / 40 \% \mathrm{RH}\right)$ and hot humid $\left(30{ }^{\circ} \mathrm{C} / 80 \% \mathrm{RH}\right)$ conditions. Equine Vet. J. 22, 70-84.

McKEEVER, K. H., T. L. EATON, S. GEISER, C. F. KEARNS, R. A. LEHNHARD (2010): Age related decreases in thermoregulation and cardiovascular function in horses. Equine Vet. J. 42, 220-227.

DOI: 10.1111/j.2042-3306.2010.00259.x

MUKAI, K., T. TAKAHASHI, D. ETO, H. OHMURA, H. TSUBONE, A. HIRAGA (2007): Heart rates and blood lactate response in Thoroughbred horses during a race. J. Equine Sci. 18, 153 160.

MUNSTERS, C. C., J. VAN DEN BROEK, R. VAN WEEREN, M. M. SLOET VAN OLDRUITENBORGH OOSTERBAAN (2013): A prospective study on fitness, workload and reasons for premature training ends and temporary training breaks in two groups of riding horses. Prev. Vet. Med. 108, 199-208.

DOI: 10.1016/j.prevetmed.2012.08.005

MUNSTERS, C. C., A. VAN IWAARDEN, R. VAN WEEREN, M. M. SLOET VAN OLDRUITENBORGH-OOSTERBAAN (2014): Exercise testing in Warmblood sport horses under field conditions. Vet. J. 202, 11-19.

DOI: $10.1016 /$ j.tvj1.2014.07.019

PADALINO, B., P. ZACCAGNINO, P. CELI (2014): The effect of different types of physical exercise on the behavioural and physiological parameters of standardbred horses housed in single stalls. Vet. Med. Int. 2014, 875051.

DOI10.1155/2014/875051

REDAELLI, V., D. BERGERO, E. ZUCCA, F. FERRUCCI, L. NANNI COSTA, L. CROSTA, F. LUZI (2014): Use of thermography techniques in equines: principles and applications. J. Equine Vet. Sci. 34, 345-50.

DOI: 10.1016/j.jevs.2013.07.007

SERRANO, M. G., D. L. EVANS, J. L. HODGSON (2002): Heart rate and blood lactate responses during exercise in preparation for eventing competition. Equine Vet. J. 34, 135-139.

DOI: 10.1111/j.2042-3306.2002.tb05406.x

Vet. arhiv 89 (1), 11-23, 2019 
N. Čebulj-Kadunc et al.: Physiological responses of Lipizzaner horses to graded exercise

SIMON, E. L., E. M. GAUGHAN, T. EPP, M. SPIRE (2006): Influence of exercise on the thermographically determined surface temperatures of thoracic and pelvic limbs in horses. J. Am. Vet. Med. Assoc. 299, 1940-1944.

DOI: $10.2460 /$ javma.229.12.1940

SLOET VAN OLDRUITENBORGH-OOSTERBAAN, M. M., T. H. WENSING, A. BARNEVELD, H. J. BREUKINK (1991): Value of standardised exercise tests and blood biochemistry in the selection and training of breeding stallions. Vet. Rec. 129, 356-359.

SLOET VAN OLDRUITENBORGH-OOSTERBAAN, M. M., H. M. CLAYTON (1999): Advantages and disadvantages of track tests versus treadmill tests. Equine Vet. J. 30, 645-648.

SLOET VAN OLDRUITENBORGH-OOSTERBAAN, M. M., E. T. VAN DEN BROEK, A. J. SPIERENBURG (2008): Evaluation of the usefulness of the portable device Lactate Pro for measurements of lactate concentrations in equine whole blood. J. Vet. Diagn. Invest. 20, 83-85.

DOI: $10.1177 / 104063870802000117$

VINCENT, T. L., J. R. NEWTON, C. M. DEATON, S. H. FRANKLIN, T. BIDDICK, K. H. McKEEVER, P. McDONOUGH, L. E. YOUNG, D. R. HODGSON, D. J. MARLIN (2006): Retrospective study of predictive variables for maximal heart rate (HRmax) in horses undergoing strenuous treadmill exercise. Equine Vet. J. 36, 146-152.

DOI: 10.1111/j.2042-3306.2006.tb05531.x.

WALLSTEN, H., K. OLSSON, K. DAHLBORN (2012): Temperature regulation in horses during exercise and recovery in a cool environment. Acta Vet. Scand. 54, 42.

DOI: $10.1186 / 1751-0147-54-42$

Received: 18 April 2018

Accepted: 27 June 2018

\section{ČEBULJ-KADUNC, N., R. FRANGEŽ, J. ŽGAJNAR, P. KRULJC: Utjecaj intenziteta vježbe na srčani i dišni sustav te tjelesnu temperaturu konja lipicanske pasmine. Vet. arhiv 89, 11-23, 2019. \\ SAŽETAK}

Sportski rezultati i uspjesi u treningu lipicanskih konja rijetko su proučavani s obzirom na njihovo rijetko sudjelovanje u konjičkim sportovima. Zbog toga nisu utvrđeni ni kriteriji za procjenu razine njihove tjelesne spreme tijekom treninga. Cilj istraživanja bio je odrediti bazalne vrijednosti različitih fizioloških pokazatelja (puls (HR), frekvencija disanja (RR), temperatura tijela i kože), kao i njihovu prilagodbu na povećanje tjelesnog opterećenja. Istraživanje je provedeno na skupini od šest čistokrvnih lipicanaca prosječne dobi 9 godina, a provedeno je u dva pokusa (u ljeto i jesen), uključujući nagla ubrzanja pri hodu, kasu i galopu. Promatrane vrijednosti mjerene su prije i poslije treninga i u oba su pokusa bile unutar očekivanih vrijednosti kod toplokrvnih konja. Postupno ubrzanje pulsa i znakovita pozitivna korelacija između pulsa i brzine kretanja dokazani su u lipicanaca tijekom treninga u oba pokusa, što je popraćeno postupnim ubrzanjem disanja i porastom rektalne temperature i temperature kože na različitim dijelovima tijela. Vrijeme potrebno za povratak pulsa na vrijednosti prije treninga bilo je dulje u proljetnom pokusu u odnosu na jesenski pokus. U jednakom je razdoblju zabilježen i povrat frekvencije disanja i rektalne tjelesne temperature. U oba su pokusa utvrđene razlike u temperaturi kože različitih dijelova tijela tijekom mirovanja. Nakon treninga temperatura koža znakovito je porasla u odnosu 
N. Čebulj-Kadunc et al.: Physiological responses of Lipizzaner horses to graded exercise

na temperaturu u mirovanju te se u jesenskom pokusu postupno vratila u normalu, dok je tijekom proljeća ostala gotovo nepromijenjena. Ovo je istraživanje pridonijelo poznavanju promjena tjelesne temperature te pokazatelja aktivnosti srčanog i dišnog sustava u konja za vrijeme povećanog tjelesnog napora. Rezultati ne pokazuju samo fiziološke promjene kod lipicanaca za vrijeme porasta intenziteta tjelesnog napora nego se i općenito mogu smatrati važnim doprinosom poznavanju fiziologije sporta i zdravlja konja, dajući temelj za daljnja istraživanja tjelesne aktivnosti i sportske medicine.

Ključne riječi: konj; puls; tjelesna temperatura; tjelesno opterećenje 
